\title{
Scope of Cooperative Learning (CL) Strategies in Teaching English to Saudi Adult EFL Learners: A Study of Practical Barriers and Possible Implications
}

\author{
Muhammad Ishtiaq ${ }^{1 *}$, Muhammad Sabboor Hussain ${ }^{2}$ \\ ${ }^{1}$ Department of Humanities and Administrative Sciences, Unaizah Community College, Qassim University, 4394 Unaizah 51911, Saudi Arabia \\ ${ }^{2}$ English Language Research Team, Preparatory Year Program, Qassim University, Saudi Arabia
}

Corresponding Author: Muhammad Ishtiaq, E-mail: m_ishtiaq_fi@yahoo.co

\section{ARTICLE INFO}

Article history

Received: June 23, 2017

Accepted: July 13, 2017

Published: December 01, 2017

Volume: 6 Issue: 7

Special Issue on Language \& Literature Advance access: September 2017

Conflicts of interest: Non Funding: None

\begin{abstract}
This study aims at investigating the teachers' practices and perceptions in teaching English in Saudi Arabia by viewing their stance on Cooperative Learning (CL) - an innovative teaching approach proposed to raise the language proficiency level of adult EFL learners. The study has been conducted in Qassim University, Saudi Arabia - a vibrant and flourishing EFL context. A quantitative tool (a questionnaire) has been used to collect data and to serve qualitative purposes. It reports 80 EFL teachers' (40 males and 40 females) perceptions about CL using a 17 -items comprehensive survey covering all the possible barriers in the way of implementing CL strategies in EFL classes. The survey items also explore how the EFL teachers in Saudi Arabia foresee the implications of making such an innovative move in their classes. The responses have been analyzed on a 5-point Likert scale which ranges from strongly disagree-disagreeneutral-agree-strongly agree. Major findings are that CL strategies have practical barriers but their implications are far more positive. The barriers are mainly due to the wrong learning habits of the adult EFL learners in Qassim University and lack of will and vision of the educational administration. The study recommends that CL strategies need to be given due consideration and support by the administrators and policy makers to raise the proficiency level of adult EFL learners. The study also allays the misconception that majority of the practitioners in English language teaching field are not ready to practice and implement $\mathrm{C}$ strategies in their classes
\end{abstract}

Key words: Adult Learners, Barriers, Cooperative Learning (CL), EFL, Implications

\section{INTRODUCTION}

The role of Cooperative Learning (CL) strategies in raising the proficiency of EFL learners to the desired level is quite crucial. In recent decades, CL has emerged as one of the major research subjects/areas due to its importance in pedagogy in general and second language (L2) research in particular. The dawn of $21^{\text {st }}$ century saw a shift of ELT paradigm from teacher-centered to learner-centered approach in English as Foreign Language (EFL) contexts all around the world. Traditional methods of teaching started being replaced by CL methods (Slavin, 2010). Researchers recognized the importance of more student-centered teaching methodologies for better English language teaching. Teacher-centered approach of standing in front of the class for the whole lecture, talking most of the time and giving home assignment was recommended to be replaced with more student-centered approach with different strategies to make the students more creative, interactive and out-put oriented (Davoudi \& Mahinpo, 2012). $\mathrm{CL}$, thus viewed, can become quite crucial in quick language proficiency enhancement of adult EF learners.

$\mathrm{CL}$ is equally important for teachers as well as students. Pre-service teachers need to learn it so that they can integrate it in their practice in order to develop learners' social, psychological and linguistic skills. Students may need to develop social and collaborative skills as they may require such skills later on in their professional careers. Kagan and Kagan (2009) believe that students can learn these skills through CL. Furthermore, teacher-student, student-teacher and student-student interaction demand an EFL teacher to be wellequipped in CL strategies.

As mentioned earlier, CL is gaining worldwide acceptance because of its effects on classroom atmosphere and learners' language proficiency (Zhou, 2012). As different learners have different skills, they share them with their group members and thus, all of them equally benefit in a group. According to Mahmoud (2014), CL changes the atmosphere of domination into an atmosphere of support and cooperation in a class. Thus instead of win-lose competition there is win-win situation. In other words, there is competition between/among groups and cooperation among group members. Van Wyk (2010) argues that CL is a teaching strategy that offers learners a social environment, active learning experience and equal opportunity. Low achievers feel satisfied that they have their peers' support and high achievers 
feel proud that they have the capability to help their teammates reach their academic goals. Saudi adult EFL learners' classes are heterogeneous but they have yet to see CL strategies in practice.

CL has also been considered as a solution to many educational problems. It can play a vital role for enhancing thinking skills, improving high order learning, and a solution to prepare learners as a collaborative work force (Slavin, 2010). It gives learners a feeling that their role is important for their teams. In teacher-fronted instruction, it is usually the teacher or some very proficient learners who dominate the whole class (Storch \& Aldosari, 2012). In CL, on the contrary, learners work together towards a common goal. They take the responsibility of their own learning and thus help one another in order to complete a task (Haydon, Maheady, \& Hunter, 2010). Thus, EFL teachers may adopt different CL strategies to help their learners develop their linguistic proficiency by giving them a chance to work together in groups, listen and respond to one another and share their learning experiences.

Conceptions and misconceptions about CL, however, need to be considered to ignite the refreshing reforms in ELT. Some teachers may think that they implement CL as their instructional strategy because they often use group work, but CL is not simply putting students in pairs or a group to work on a task (Wallestad, 2010). Others may think that it is difficult to implement CL as compared to teaching in traditional teacher-fronted whole class instruction. According to Kohn (1992), some teachers may be reluctant to use CL arguing that it is difficult to control communication in the class when CL strategies are used. Such teachers are probably apprehensive of the negative assessment of the administrators who are usually intolerant towards noisy and vibrant classes. Lack of training may also cause a hindrance in implementing CL techniques and moves. Moreover, teachers who do not have any training in CL may have different perceptions than those of the trained teachers. According to Heath (2010), teachers may think that it is more time-consuming especially when they have no experience of using CL. These conceptions and misconceptions need to be investigated in a country like Saudi Arabia where English is being quickly accepted in academia but is still resisted in society in general.

Saudi Arabia is a unique multicultural society with excessive use of Arabic in all walks of life. Arabic is the dominant language, perhaps the only living language, in the kingdom. English was the only foreign language taught at intermediate and secondary level in 1984 (Maherzi, 2011). Implementation of CL and other innovative methods of teaching still seem to be at an impractical stage. There may be many reasons for adherence to the traditional methods of teaching. Some teachers are unwilling to change their teaching practices and find contentment in using traditional methods of teaching English to Saudi adult learners. Others may not have experience or training to apply different CL strategies. There is a research need to explore reasons for the reluctance in bringing reforms and innovations in teaching practices in Saudi context in spite of the growing acceptance of English more in academic institutions and gradually and slowly in the society. The current study tends to find out whether it is because the traditional methods are easier to adopt for Saudi EFL teachers, and other strategies are more time-consuming and challenging. Perhaps, Saudi EFL classrooms are in dire need of pedagogical changes where more student-centered techniques are waiting for their turn. Therefore, there is a strong quest to investigate EFL teachers' practices and perceptions in CL to find out the practical barriers and implications. This study is a step forward in this direction as it investigates the scope of CL in Saudi Arabia as seen by EFL teachers.

\section{Statement of Problem}

Saudi EFL scenario is quite unique in many ways. In spite of the best efforts of teachers, best syllabus and best teaching aids available to the teachers in the classroom, the proficie cy level of the adult learners does not reach the desired level. This study starts with the hypothetical stance that CL strategies might be a solution to the problem. The practitioners need to be approached to reach their perceptions and opinions about practical barriers in the way of CL based teaching and possible implications of introducing CL strategies in EFL classrooms. EFL teachers in Saudi Arabia overlook or are forced to overlook the pedagogic tenets which need to be taken into serious consideration. Traditional methods of teaching are considered the only solution to all kinds of classes and for all levels of students. According to Assalahi (2013), some teachers are unwilling to change their traditional method of teaching. They fail to incorporate different teaching strategies to develop social and linguistic skills in adult learners given under their charge. According to Javid, Farooq, and Gulzar (2012), some teachers either do not know or they do not bother to use different and innovative instructional techniques. Majority of the EFL teachers in Saudi Arabia are native speakers of Arabic, therefore; Arabic is the language of the classrooms even in EFL classes (Ishtiaq, Ali $\&$ Salem, 2015). Traditional methods of teaching should not come as a surprise in such situations. Abdel Rauf (2010) argues that Grammar Translation Method (GTM) dominates the Arab world and there is a need to investigate new approaches like CL in teaching English to adult learners.

Thus the present study tends to find answers to the following research questions:

1. What is the scope of Cooperative Learning (CL) strategies in teaching English to Saudi adult learners?

2. How do male and female EFL teachers differ in their attitude towards Cooperative Learning based teaching to Saudi adult EFL t learners?

\section{LITERATURE REVIEW}

Cooperative learning (CL) means working together to achieve common academic goals. In CL, students help one another, take the responsibility of their own learning, take care of others, teach others and in return enhance their own understanding (Johnson, 2009, as cited in Tran, 2014). Chianson, Kurumeh, and Obidah (2010) argue that when students explain something to others or other students ex- 
plain to them, they develop better understanding of the subject matter which leads to deeper retention that lasts for a longer time. According to Kagan and Kagan (2009), in CL the students work together in small groups to achieve a common goal and are responsible for their own learning as well as their team's learning. Thus, CL aims to give adult EFL learners an opportunity to work together and become more responsible and proficient learners

$\mathrm{CL}$ is an instructional method in which small groups of learners work together and help one another to learn academic content (Slavin, 2011). In CL, five to six students work in heterogeneous groups, share knowledge, help and get help from others and try to find a solution to a problem collectively. According to Van Wyk (2010), CL is a teaching strategy that offers learners a social environment, an active learning experience and equal opportunity. Thus CL not only gives learners a chance to practice the required material, it also develops their social skills. CL enhances social and personal development because students are required to work together on problems, try to find their solutions and achieve their academic goals (Mohseny, \& Jamour, 2012). CL is not just a group work; it is an opportunity for everyone to participate in a collective task to develop their social skills (Van Wyk, 2012). According to Davoudi and Mahinpo (2012), CL improves social skills, language skills and enhances chances of employability. Therefore, if CL is used in Saudi EFL classrooms, it may help them learn new material and develop their social skills to prepare them properly for the job market.

The whole class instruction may not give learners an opportunity to talk to other students or to their teachers. On the contrary, in CL, they help one another to comprehend the given material which increases their oral language proficiency (Zhou, 2012). In traditional classrooms, there is little opportunity for teachers to give individual attention to every single student, which is hardly any issue in CL (Khan, Javaid, \& Farooq, 2015). The teacher can freely move around the class, monitor students and provide them help if they need. CL has emerged as an important student-centered teaching approach among social science researchers and practitioners in the teaching field. It has been found more effective as compared to lecture based teaching as far as the cognitive and affective domains of adult learners are concerned (Slavin, 2011). In some cultures, learners do not work hard for individual achievement but when they work in groups, they feel more motivated to get a win for their groups (Kagan \& Kagan, 2009). Thus, EFL teachers should try to use different strategies to motivate their students to work for common academic goals and thus develop their communicative skills.

CL promotes learner-learner, learner-teacher and teacher-learner interaction and gives learners self-confidence to take the responsibility of their learning. In CL, students develop more positive relationship with other students and teachers, develop self-esteem and start liking the concerned subject (Slavin, 2011). CL develops a sense of achievement because every student tries to learn and help his team mates to learn the given material (Mohseny, \& Jamour, 2012). According to Wang, (2012), in CL, learners work togeth- er in groups and try to achieve a common goal and teacher serves as a facilitator; shifting the responsibility of learning to learners. EFL teachers in Saudi Arabia may try different CL strategies in order to enhance their learners' self-confidence and give them responsibility of their own learning. This might lead to the desired direction/target of raising the language proficiency level of the learners

In some cultures, traditional methods of teaching are so popular that EFL teachers may view the implementation of CL strategies as something impossible. Assalahi (2013) argues that some teachers are unwilling to change their traditional method of teaching despite being trained by professional educators. EFL teachers need to incorporate different teaching strategies in order to help their learners improve their language proficienc . However, use of alternative strategies in EFL classrooms seems to be a hard task for some teachers. Heath (2010) conducted a study on the impact of CL training program on teacher perceptions about CL. The author reported that training could not change teachers' perceptions of CL. Therefore, it will be important to know how EFL teachers in Saudi Arabia conceive the implementation of CL strategies in their classrooms.

A great deal of previous research has reported the effectiveness of CL strategies. Law (2011), Mahmoud (2014), Khan, Javaid and Farooq (2015), Pan and Wu (2013), and Wang (2012) have reported that CL strategies are effective in improving learners' language proficienc . However, some studies have found no significant difference between CL strategies and traditional methods of teaching. Ishtiaq, Ali and Salem (2015) investigated the effects of Student Teams Achievement Division (STAD) on motivation of Saudi adult EFL learners and reported that there was no significant difference between the experimental group and the control group in their motivation towards learning. Similarly, Zain, Subramaniam, Rashid and Ghani (2009) and Khan and Inamullah (2011) reported that there was no significant difference between the students using CL method and those using conventional/traditional method. It should also be noted here that all these studies thus mentioned have focused on students and there is a dearth of research on teachers' perceptions about the use of CL strategies in purely EFL context. The current study is an attempt to find out the views of EFL teachers in Saudi Arabia about CL strategies.

Historically, CL has been linked with different factors leading to learner-centered learning/teaching. There are 150 Kagan's structures of CL that give an opportunity to learners to participate, have peer support and get motivated (Davoudi \& Mahinpo, 2012). Other researchers have put forward different aspects of CL. Slavin (1995) argues that CL has three important features: first, learners work in small groups of two to six members. Second, it is a structured learning that ensures that every member in the group is able to perform a learning task. Third, students depend on each other to achieve their learning objectives (as cited in Wang, 2009). The third factor - interdependence has received special consideration in CL strategies. CL is gaining worldwide acceptance because of its effects on classroom atmosphere and learners' language proficiency (Zhou, 2012). Recent studies 
show that peer collaboration is one of the key components in L2 learning process (Alijanian, 2012). This is especially important in Saudi EFL classrooms where learners have little or no chance to collaborate. According to Johnson and Johnson (2009), CL is a widely used strategy because of the fact that two heads are better than one and secondly, because a lot of research has shown that it has been an effective strategy in classrooms. However, scope of applying CL strategies in Saudi EFL classrooms still needs to be researched.

CL can be divided into two categories: (a) Structured Team Learning that demands every individual to be responsible for his learning and the teams are rewarded on the basis of individual improvement.(b) informal group learning that focuses on projects, discussions and social development (Slavin, 2010). Following is a brief elaboration of major categories of CL:

\section{Structured Team Learning Methods}

According to Slavin (2010), there are three factors in Structured Team Learning: (STL); team rewards, individual accountability and equal opportunities for success. He explains that STL rewards students on their improvement over their previous score and not in comparison with other students. Thus learners try to work harder to improve their scores. According to Wang (2009), if students are rewarded for their improvement over their previous score, they will be more motivated to learn. When learners feel that their teams will win or lose because of their roles in their teams, they feel responsibility and try to work for their teams.

Individual accountability is an important factor that has been supported by the findings of some experimental studies (Slavin, 2009). Individual accountability means that success of a team depends on learning of every individual in a team (Wang, 2009). This ensures that every team member has to play his/her part for the team. Tran (2014) argues that if students are not accountable for their learning, they may rely on others to complete the given task. This may disengage them and the whole idea of cooperation may fail. Equal opportunity means that every team member, whether s/he is a high, average or low achiever, has an equal opportunity to contribute to the success of the team (Wang, 2009). If EFL learners in Qassim University are given responsibility and equal chance to work for their team, it may have a positive effect on their linguistic competence.

STL makes sure that all team members work together on the principle of mutual cooperation. In STL, learners work towards a common goal in the same teams for several weeks (Heath, 2010). This develops social ties among the team-mates. STL has four different methods: Student Team Achievement Division (STAD), Teams-Games-Tournament (TGT), Team Assisted Individualization (TAI) and Cooperative Integrated Reading and Composition (CIRC) (Slavin, 2010). Following is a brief description of these four methods:

\section{Student teams achievement division (STAD)}

Student Teams Achievement Division (STAD) is a structured learning strategy that was developed by Slavin (1995) at John Hopkins University (as cited in VanWyk, 2012). In STAD, students are assigned to/divided in small groups where they cooperate with one another to achieve a common academic goal. There are five steps of STAD viz., (i) heterogeneous groups are formed based on the learners' academic achievement (ii) the teacher gives instruction (iii) learners help one another to understand the material given by the teacher in the form of worksheets (iv) learners take individual quizzes and are not allowed to help one another (v) high scoring teams are rewarded with some kind of certificate or their names are written on the bulletin board (Slavin, 1995).

\section{Teams-games-tournament (TGT)}

In Teams-Games-Tournament, teacher gives instructions and students work in teams as in STAD but instead of quizzes, students have tournaments (Slavin, 1994, as cited in Slavin, 2010). Students compete at three person table competition and every student is given an equal chance to win (Slavin, 2011).

\section{Team assisted individualization (TAI)}

TAI uses the same structure as STAD and TGT. However, there are two marked differences that make it different from these two strategies: (i) it mixes group work with individualized instruction (ii) it was specially designed for mathematics students (Slavin, 2011).

\section{Cooperative integrated reading and composition (CIRC)}

CIRC is a comprehensive program to develop reading and writing skills in learners (Stevens et al., 1987, as cited in Slavin, 2010). Students work on a series of activities, for example, read to one another, make predictions, summarize stories and write responses to stories in the teams composed of two pairs from two different reading groups (Slavin, 2011).

\section{Informal Group Learning Methods}

In informal group learning methods, learners stay in groups for a few activities. Informal group learning methods require students to work for a short period of time for a specific activity (Heath, 2010). Informal group learning methods include jigsaw, learning together and group investigation.

\section{Jigsaw}

Jigsaw uses the same methods of individual improvement scores and team recognition as those of STAD. Jigsaw was designed by Elliot Aronson and his colleagues in 1978 (Slavin, 2011). The students in this CL strategy work in groups of six. Each member reads his part and later on meets the other member in a new group (expert group) who has read the same part and finally goes back to his original group to discuss the whole reading passage (Slavin, 2010). 


\section{Learning Together}

In this method, students work together in groups of four or five and complete a single worksheet. It was developed by Johnson and Johnson in 1999 (as cited in Slavin, 2010).

\section{Group Investigation}

Group investigation was developed by Sharan and Sharan (1992) in which students work in small groups with inquiry, discussion and planning (as cited in Slavin, 2011). Students work in groups choosing sub-topics for individual tasks and then every group presents its findings to the entire class (Slavin, 2011).

Contrary to the above mentioned CL strategies and techniques, informal and traditional learning methods are devoid of the elements that are part and parcel of CL. In the absence of individual accountability, for instance, some learners may not participate. They may become free-riders and leave the job done by their more motivated and competent classmates (Kagan, 2009). Moreover, students may not develop a social bond among them since they do not remain in the same groups (teams) for a long time as they do in structured learning methods.

The current study focuses on both the formal and informal methods of CL in sharp contrast to the traditional methods. It is an attempt to investigate possible implications and practical hindrances that teachers may face while applying CL strategies in their classrooms. Only teachers were required to participate in the study, however, the study will also benefit EFL learners in general and adult EFL learners in Saudi Arabia in particular.

\section{RESEARCH METHODOLOGY}

The study uses quantitative research approach to explore the issue "to fill missing gaps and under-researched area" (Strokes \& Wall, 2014, p-89) of EFL teachers' perception about the CL strategies. It is also a descriptive research as it "aims to elaborate current topic with a view to deepening understanding of it" (Strokes \& Wall, 2014, p-89). Though the research objective is to get a deeper understanding of the barriers and implications of CL strategies in EFL context in Saudi Arabia, the use of quantitative tool has given it yet another dimension by making it generalizable to other EFL contexts in other parts of the world. Thus, in spite of remaining positioned in interpretivistic paradigm and qualitative perspective, the quantitative tool of survey has given it double dimensions as on one hand it measures the depth and on the other hand the width. Following is the explanation of the research design used in this research study.

\section{Population and Sampling}

Eighty teachers from diversified backgrounds (forty males and forty females) participated in the present study. These teachers belonged to different countries. Some of them were from Saudi Arabia but others belonged to other Arab and non-Arab countries. A few of them were from native English speaking countries. Like their backgrounds, the teaching experience of the participants also varied. Fifty four percent of the participants (both males and females) had above ten years' experience. Twenty eight percent of them had between six to ten years' experience and nineteen percent of them had less than five years experience.

\section{Procedure}

The study was conducted in Qassim University, Saudi Arabia. EFL teachers teaching in different colleges of Qassim University participated in the study. A questionnaire was distributed with the permission of the deanship of research in Qassim University. It was made clear to the participants that their participation would be voluntary and that their responses would remain anonymous and would be kept confidential. The questionnaire was re-collected in two weeks' time.

\section{Data Collection Instruments}

A 17-item questionnaire on a five point Likert scale was prepared by the researchers. The questionnaire was sent to three professors to check for appropriateness of the items. Their suggestions were considered in the final draft of the questionnaire. The questionnaire was piloted on 25 participants. Reliability of the instrument was calculated through Cronbach's alpha and it was found reliable $(\alpha=0.72)$. The data was collected in the fall semester 2016. SPSS 21 was used to analyze the data. Chi-square test and Independent samples t-test were used in the analysis.

\section{RESULTS AND ANALYSIS}

Findings of the questionnaire survey have revealed that most of the participants/EFL teachers believe that CL should be implemented in Saudi adult EFL learners' classes implying thereby that there is a willingness among the majority to bring reforms in the teaching practices to raise the English proficiency of the learners. Following is the detailed analysis of the responses from the male and female EFL teachers:

Table 1 shows the male and the female participants' responses to item-1 in the questionnaire. Fifty percent of the female participants and $52.5 \%$ of the male participants agree that $\mathrm{CL}$ is an important teaching strategy which needs to be implemented in Saudi adult EFL learners' classes. No female participant has disagreed and only five percent of the male participants have disagreed to it. Therefore, it will be safe to conclude that EFL teachers in Saudi Arabia are in favor of using CL strategies in Saudi adult EFL learners' classes and they are not or do not want to be the barriers in the implementation process.

Table 2 presents the male and the female participants' responses to item-2 in the questionnaire. Findings have revealed that an overwhelming majority of the female participants believe that Saudi adult EFL learners are used to traditional methods of teaching. Therefore, teachers face problems in integrating CL strategies in their teaching practice in Saudi adult learners' classes. Fifty percent of the male participants also believe that they cannot implement CL 
Table 1. Male vs. female responses to item-1 in the auestionnaire

\begin{tabular}{lcc}
\hline \begin{tabular}{l} 
Cooperative learning $(\mathrm{CL})$ \\
is an important teaching \\
strategy which needs to be \\
implemented in Saudi adult \\
\cline { 2 - 3 } learners' classes
\end{tabular} & \multicolumn{2}{c}{ Gender } \\
\hline Strongly disagree & 5.0 & Female (\%) \\
Neutral & 5.0 & 000 \\
Agree & 52.5 & 7.5 \\
Strongly agree & 37.5 & 50.0 \\
Total & 100.0 & 42.5 \\
\hline
\end{tabular}

Table 2. Male vs. female responses to item-2 in the questionnaire

\begin{tabular}{|c|c|c|}
\hline \multirow[b]{2}{*}{$\begin{array}{l}\text { Teachers face problems in } \\
\text { integrating CL strategies in } \\
\text { their teaching practices in } \\
\text { Saudi adult learners' classes } \\
\text { as the learners are used to } \\
\text { learning with traditional } \\
\text { methods of teaching }\end{array}$} & \multicolumn{2}{|c|}{ Gender } \\
\hline & Male (\%) & Female (\%) \\
\hline Strongly disagree & 2.5 & 0.00 \\
\hline Disagree & 10.0 & 7.5 \\
\hline Neutral & 25.0 & 7.5 \\
\hline Agree & 52.5 & 75.0 \\
\hline Strongly agree & 10.0 & 10.0 \\
\hline Total & 100.0 & 100.0 \\
\hline
\end{tabular}

strategies because learners are used to learning with traditional methods of teaching. This shows that the barriers in the way of integrating CL strategies are from the learners and not from the teachers. Therefore, the rectification of the bad learning habits of adult EFL learners is required to put them on the track of quick and efficient English language teaching/learning.

Table 3 shows that 55 percent of the female participants believe that teachers face problems in integrating CL strategies in their teaching practices in Saudi adult EFL learners' classes as the teachers are used to teaching with traditional methods of teaching. However, 25 percent of the male participants disagree to it. This is another researchable area to find out the factors which force the EFL teachers to go on the traditional track of teaching instead of bringing reforms and innovations in their teaching approaches, methods and techniques.

Table 4 reveals that most of the participants believe that EFL teachers in Saudi Arabia can develop learners' social, collaborative, psychological and linguistic skills by using CL strategies. Fifty percent of the male participants and forty five percent of the female participants have agreed to it. However, 30 percent of the male participants and 20 percent of the female participants have strongly agreed to it. Therefore, it can be concluded that EFL teachers in Saudi Arabia can develop learners' social, collaborative, psychological
Table 3. Male vs. female responses to item-3 in the questionnaire

\begin{tabular}{lcc}
\hline Teachers face problems in & \multicolumn{2}{c}{ Gender } \\
\cline { 2 - 3 } $\begin{array}{l}\text { integrating CL strategies in } \\
\text { their teaching practices in }\end{array}$ & Male (\%) & Female (\%) \\
$\begin{array}{l}\text { Saudi adult learners' classes } \\
\text { as the teachers are used to } \\
\text { teaching with traditional }\end{array}$ & & \\
methods of teaching & & \\
\hline Strongly disagree & 12.5 & 5.0 \\
Disagree & 25.0 & 15.0 \\
Neutral & 27.5 & 17.5 \\
Agree & 22.5 & 55.0 \\
Strongly agree & 12.5 & 7.5 \\
Total & 100.0 & 100.0 \\
\hline
\end{tabular}

Table 4. Male vs. female responses to item-4 in the questionnaire

\begin{tabular}{lcc}
\hline EFL teachers in Saudi Arabia & \multicolumn{2}{c}{ Gender } \\
\cline { 2 - 3 } $\begin{array}{l}\text { can develop learners' social, } \\
\text { collaborative, psychological } \\
\text { and linguistic skills by using }\end{array}$ & Male (\%) & Female (\%) \\
CL strategies & & \\
\hline Strongly disagree & 5.0 & 0.00 \\
Disagree & 2.5 & 00 \\
Neutral & 12.5 & 35.0 \\
Agree & 50.0 & 45.0 \\
Strongly agree & 30.0 & 20.0 \\
Total & 100.0 & 100.0 \\
\hline
\end{tabular}

and linguistic skills by using CL strategies and they have no doubts about the utility of CL strategies in raising the proficiency level of adult EFL learners.

Table 5 illustrates that most of the participants disagree to the idea that teachers are unable to use CL strategies to develop teacher-student, student-student and student-teacher interaction in the class as Saudi adult learners do not want to work with others. Forty percent of the female participants and 35 percent of the male participants have disagreed to it. Ten percent of the male participants have strongly disagreed to it. However, 30 participants of the female participants and 20 percent of the male participants believe that Saudi adult learners resist working with others; therefore, teachers cannot implement CL strategies in their classes.

Table 6 presents the male and female respondents' responses to item- 6 . According to these findings, most of the participants agree that CL strategies can change the atmosphere of the classroom from traditional to modern and help develop the adult learners' language proficienc. Fifty three percent of the female participants agree and forty percent of them strongly agree to it. Similarly, 45 percent of the male participants agree and 50 percent of them strongly agree that CL can change the atmosphere of the classroom from traditional to modern and can help develop adult EFL learners' language proficienc . 
Table 5. Male vs. female responses to item-5 in the questionnaire

\begin{tabular}{lcc}
\hline $\begin{array}{l}\text { Teachers' efforts to } \\
\text { develop teacher-student, } \\
\text { student-student and } \\
\text { student- teacher interaction } \\
\text { in the class as a result of CL } \\
\text { strategies are resisted by }\end{array}$ & Male (\%) & Female (\%) \\
$\begin{array}{l}\text { Saudi adult learners as they } \\
\text { don't want to work with } \\
\text { others }\end{array}$ & & \\
\hline Strongly disagree & & \\
Disagree & 10.0 & 0.00 \\
Neutral & 35.0 & 40.0 \\
Agree & 22.5 & 20.0 \\
Strongly agree & 20.0 & 30.0 \\
Total & 12.5 & 10.0 \\
\hline
\end{tabular}

Table 6. Male vs. female responses to item-6 in the questionnaire

\begin{tabular}{lcc}
\hline If different CL strategies & \multicolumn{2}{c}{ Gender } \\
\cline { 2 - 3 } $\begin{array}{l}\text { are used in the class, they } \\
\text { can change the classroom } \\
\text { atmosphere from traditional } \\
\text { to modern and help develop } \\
\text { the adult learners' language }\end{array}$ & Male (\%) & Female (\%) \\
proficiency & & \\
\hline Strongly disagree & 2.5 & 2.5 \\
Disagree & 0.00 & 2.5 \\
Neutral & 2.5 & 2.5 \\
Agree & 45.0 & 52.5 \\
Strongly agree & 50.0 & 40.0 \\
Total & 100.0 & 100.0 \\
\hline
\end{tabular}

Table 7 reveals that most of the participants agree that the atmosphere of cooperation among the team-mates and competition among the teams can make Saudi adult learners more proficient language learners. Forty percent of the female participants agree and 50 percent of them strongly agree to it. Similarly, 50 percent of the male participants agree and 33 percent strongly agree that CL strategies can make Saudi adult learners more proficient language learners.

Table 8 shows that most of the participants agree that CL strategies can give Saudi adult EFL learners a social environment, active learning experience and equal opportunity to learn the target language. Thirty three percent of the female participants agree and 60 percent of them strongly agree to it. Similarly, 48 percent of the male participants agree and 35 percent of them strongly agree that CL strategies can give Saudi adult EFL learners a social environment, active learning experience and equal opportunity to learn the target language.

Table 9 shows that most of the male and female participants believe that EFL teachers should adopt different CL strategies as they are equally beneficial for high, medium
Table 7. Male vs. female responses to item-7 in the questionnaire

\begin{tabular}{lcc}
\hline $\begin{array}{l}\text { The atmosphere of } \\
\text { cooperation among the } \\
\text { team-mates and competition } \\
\text { among the teams as a result } \\
\text { of CL strategies can make }\end{array}$ & Male (\%) & Female (\%) \\
$\begin{array}{l}\text { Saudi adult learners more } \\
\text { proficient language learners }\end{array}$ & & \\
\hline Strongly disagree & 2.5 & 0.00 \\
Neutral & 15.0 & 10.0 \\
Agree & 50.0 & 40.0 \\
Strongly agree & 32.5 & 50.0 \\
Total & 100.0 & 100.0 \\
\hline
\end{tabular}

Table 8. Male vs. female responses to item- 8 in the questionnaire

\begin{tabular}{lcc}
\hline $\begin{array}{l}\text { CL strategies can give } \\
\text { Saudi adult learners a } \\
\text { social environment, active }\end{array}$ & \multicolumn{2}{c}{ Gender } \\
\cline { 2 - 3 } $\begin{array}{l}\text { learning experience and equal } \\
\text { opportunity to learn the } \\
\text { target language }\end{array}$ & & Fale (\%) \\
\hline Strongly disagree & 2.5 & 0.00 \\
Neutral & 15.0 & 7.5 \\
Agree & 47.5 & 32.5 \\
Strongly agree & 35.0 & 60.0 \\
Total & 100.0 & 100.0 \\
\hline
\end{tabular}

and low achievers in the adult learners' classes. Fifty percent of the male participants and the same percentage of the female participants agree to it. Similarly, 38 percent of the male participants and 43 percent of the female participants strongly agree that EFL teachers should adopt different CL strategies.

Table 10 illustrates male and female participants' responses to item-10. Seventy percent of the male participants and 45 percent of the female participants agree that the teachers can help develop Saudi adult EFL learners' self-confidence by encouraging them to participate actively in different $\mathrm{CL}$ strategies. Another 25 percent of the male participants and 50 percent of the female participants strongly agree to it.

Table 11 illustrates that 63 percent of the male participants and 53 percent of the female participants agree that if different CL strategies are used in the class, they will make Saudi adult learners more responsible and thus the teachers' task will become easier. Another 15 percent of the male participants and 30 percent of the female participants strongly agree to it.

Table 12 represents responses of male and female participants to item-12. The findings reveal that most of the participants agree to item 12 . Fifty percent of the male participants and 55 percent of the female participants agree that if different CL strategies are used in the class, they will make Saudi adult EFL learners more motivated as compared to working 
Table 9. Male vs. female responses to item-9 in the questionnaire

\begin{tabular}{lcc}
\hline EFL teachers should adopt & \multicolumn{2}{c}{ Gender } \\
\cline { 2 - 3 } $\begin{array}{l}\text { different CL strategies as } \\
\text { they are equally beneficial } \\
\text { for high, medium and }\end{array}$ & Male (\%) & Female (\%) \\
low achievers in the adult & & \\
learners' classes & & \\
\hline Strongly disagree & 2.5 & 0.00 \\
Disagree & 00 & 2.5 \\
Neutral & 10.0 & 5.0 \\
Agree & 50.0 & 50.0 \\
Strongly agree & 37.5 & 42.5 \\
Total & 100.0 & 100.0 \\
\hline
\end{tabular}

Table 10. Male vs. female responses to item-10 in the questionnaire

\begin{tabular}{lcc}
\hline $\begin{array}{l}\text { EFL teachers can help } \\
\text { develop Saudi adult } \\
\text { learners' self-confidence } \\
\text { by encouraging them to } \\
\text { participate actively in } \\
\text { different CL strategies }\end{array}$ & Male (\%) & Female (\%) \\
\hline Strongly disagree & & \\
Neutral & 2.5 & 0.00 \\
Agree & 2.5 & 5.0 \\
Strongly agree & 70.0 & 45.0 \\
Total & 25.0 & 50.0 \\
\hline
\end{tabular}

Table 11. Male vs. female responses to item-11 in the questionnaire

\begin{tabular}{lcc}
\hline If different CL strategies & \multicolumn{2}{c}{ Gender } \\
\cline { 2 - 3 } $\begin{array}{l}\text { are used in the class, they } \\
\text { will make Saudi adult }\end{array}$ & Male (\%) & Female (\%) \\
$\begin{array}{l}\text { learners more responsible } \\
\text { and thus the teachers' task } \\
\text { will become easier }\end{array}$ & & \\
\hline Strongly disagree & 5.0 & 0.00 \\
Disagree & 7.5 & 0.00 \\
Neutral & 10.0 & 17.5 \\
Agree & 62.5 & 52.5 \\
Strongly agree & 15.0 & 30.0 \\
Total & 100.0 & 100.0 \\
\hline
\end{tabular}

individually. Another 22 percent of the male participants and 30 percent of the female participants strongly agree to it.

Table 13 shows responses of male and female participants to item 13. According to the findings, 63 percent of the male participants and 60 percent of the female participants agree that EFL teachers can develop a sense of achievement in Saudi adult EFL learners by using different CL strategies. Another 20 percent of the male and 23 percent of the female participants strongly agree to it.
Table 12. Male vs. female responses to item-12 in the questionnaire

\begin{tabular}{lcc}
\hline If different CL strategies are & \multicolumn{2}{c}{ Gender } \\
\cline { 2 - 3 } $\begin{array}{l}\text { used in the class, they will } \\
\text { make Saudi adult learners } \\
\text { more motivated as compared } \\
\text { to working individually }\end{array}$ & Male (\%) & Female (\%) \\
\hline Strongly disagree & 2.5 & 0.00 \\
Disagree & 10.0 & 2.5 \\
Neutral & 15.0 & 12.5 \\
Agree & 50.0 & 55.0 \\
Strongly agree & 22.5 & 30.0 \\
Total & 100.0 & 100.0 \\
\hline
\end{tabular}

Table 13. Male vs. female responses to item-13 in the questionnaire

\begin{tabular}{lcc}
\hline EFL teachers can develop & \multicolumn{2}{c}{ Gender } \\
\cline { 2 - 3 } $\begin{array}{l}\text { a sense of achievement in } \\
\text { Saudi adult learners by using } \\
\text { different CL strategies }\end{array}$ & Male (\%) & Female (\%) \\
\hline Strongly disagree & 2.5 & 0.00 \\
Neutral & 15.0 & 17.5 \\
Agree & 62.5 & 60.0 \\
Strongly agree & 20.0 & 22.5 \\
Total & 100.0 & 100.0 \\
\hline
\end{tabular}

Table 14 shows that most of the participants (both male and female) agree that CL strategies can give Saudi adult EFL learners more opportunity to talk as compared to traditional methods of teaching. Thirty percent of the male participants and 60 percent of the female participants agree to it. Another 48 percent of the male participants and 35 percent of the female participants strongly agree that CL strategies can give Saudi adult learners more opportunity to talk as compared to traditional methods of teaching.

Table 15 shows responses of male and female participants to item-15. According to the findings, only 35 percent of the male participants and 50 percent of the female participants agree that CL strategies are more time-consuming as compared to the traditional methods of teaching. Similarly, only 23 percent of the male participants and 13 percent of the female participants strongly agree to it. This particular finding strongly refutes the general misperception about the use of CL strategies in the EFL classes.

Table 16 shows responses of male and female participants to item-16. According to the findings, only 33 percent of the male and 23 percent of the female participants agree that it is difficult to control communication in using CL strategies in Saudi Arabia as the class becomes messy and noisy. The administrators and the class observers observing the EFL teachers for evaluation purposes need to change their way of thinking and take the noisy classes as vibrant ones where real learning is taking place in the most modern way using the CL strategies. This will encourage EFL teachers to use CL strategies in EFL classes when they get the surety that 
Table 14. Male vs. female responses to item-14 in the questionnaire

\begin{tabular}{lcc}
\hline CL strategies can give & \multicolumn{2}{c}{ Gender } \\
\cline { 2 - 3 } $\begin{array}{l}\text { Saudi adult learners more } \\
\text { opportunity to talk as } \\
\text { compared to traditional } \\
\text { methods of teaching }\end{array}$ & Male (\%) & Female (\%) \\
\hline Strongly disagree & 2.5 & \\
Disagree & 12.5 & 0.00 \\
Neutral & 7.5 & 0.00 \\
Agree & 30.0 & 5.0 \\
Strongly agree & 47.5 & 60.0 \\
Total & 100.0 & 35.0 \\
\hline
\end{tabular}

Table 15. Male vs. female responses to item-15 in the questionnaire

\begin{tabular}{lcc}
\hline $\begin{array}{l}\text { CL strategies are more } \\
\text { time-consuming as } \\
\text { compared to the traditional } \\
\text { methods of teaching }\end{array}$ & \multicolumn{2}{c}{ Gender } \\
\cline { 2 - 3 } & Male (\%) & Female (\%) \\
\hline Strongly disagree & 2.5 & 0.00 \\
Disagree & 27.5 & 17.5 \\
Neutral & 12.5 & 20.0 \\
Agree & 35.0 & 50.0 \\
Strongly agree & 22.5 & 12.5 \\
Total & 100.0 & 100.0 \\
\hline
\end{tabular}

Table 16. Male vs. female responses to item-16 in the questionnaire

\begin{tabular}{lcc}
\hline $\begin{array}{l}\text { It is difficult to control } \\
\text { communication in using CL } \\
\text { strategies in Saudi Arabia as } \\
\text { the class becomes messy and } \\
\text { noisy }\end{array}$ & Male (\%) & Female (\%) \\
\hline Strongly disagree & 12.5 & 25.0 \\
Disagree & 25.0 & 35.0 \\
Neutral & 25.0 & 17.5 \\
Agree & 32.5 & 22.5 \\
Strongly agree & 5.0 & 0.00 \\
Total & 100.0 & 100.0 \\
\hline
\end{tabular}

they will not be alleged to be ill-disciplined and poor class managers if they make the classes totally student-centered using CL strategies.

Table 17 illustrates responses of the male and the female participants to item-17. According to the findings, 33 percent of the male participants and 65 percent of the female participants agree that a teacher needs a lot of training in order to use CL strategies effectively in EFL contexts in general and in Saudi EFL context in particular. Twenty percent of the male participants strongly agree to it. In-service, pre-service training and refresher courses can be very handy and
Table 17. Male vs. female responses to item-17 in the questionnaire

\begin{tabular}{lcc}
\hline $\begin{array}{l}\text { A teacher needs a lot of } \\
\text { training in order to use CL } \\
\text { strategies effectively in Saudi } \\
\text { context }\end{array}$ & \multicolumn{2}{c}{ Gender } \\
\cline { 2 - 3 } Strongly disagree & 5.0 & Female (\%) \\
Disagree & 27.5 & 0.00 \\
Neutral & 15.0 & 17.5 \\
Agree & 32.5 & 65.0 \\
Strongly agree & 20.0 & 7.5 \\
Total & 100.0 & 100.0 \\
\hline
\end{tabular}

Table 18. Independent samples t-test of the two groups (male and female)

\begin{tabular}{lcccc}
\hline & $\boldsymbol{N}$ & Mean \pm SD & $\boldsymbol{t}$ & Significant \\
\hline Male & 40 & $3.76 \pm 0.52$ & -2.07 & 0.04 \\
Female & 40 & $3.97 \pm 0.38$ & & \\
\hline
\end{tabular}

effective for successful CL strategies implementation in EFL classes.

Table 18 shows the independent samples t-test of the male and the female respondents. The findings reveal that there is a difference between the mean scores of the male participants (3.76) and the female participants (3.97). This difference is significant at (.05) level. The female participants scored significantly higher than the male participants

\section{DISCUSSION}

Findings have revealed that most of the participants (both males and females) believe that CL has a wider scope in Saudi adult EFL learners' classes. Majority of the participants agree that application of CL in their classes will improve their learners' social, collaborative, psychological and linguistic skills. Participants (both males and females) also believe that CL strategies can help motivate Saudi EFL learners as compared to working alone as is the case in traditional methods of teaching. These findings contradict with those reached by Heath (2010). Heath (2010) investigated the impact of CL training program on teacher perceptions about CL. The fin ings revealed professional development training in CL did not change teachers' perceptions of CL. On the contrary, finding of the current study suggest that EFL teachers in Saudi Arabia perceive CL strategies as effective teaching techniques that should be welcomed in Saudi EFL classrooms.

An interesting finding to note is that a vast majority of the female participants $(75 \%)$ are of the opinion that they cannot use CL strategies in their classrooms because learners are used to learning with traditional methods of teaching. Another important finding reveals that seventy (70) percent of the male participants agree that CL strategies are a source of boosting learners' self-confidence. However, most of the female participants $(65 \%)$ also believe that teachers need a lot of training to use CL strategies in their classrooms. 
Findings have also revealed that there is a significant difference between the male and the female participants' responses to the questionnaire. Female participants scored significantly higher score as compared to the male participants. These findings are in line with those reached by Zhou (2012), Gillies and Boyle (2010). However, according to Gillies' and Boyle's (2010) study, some teachers reported that implementation of CL was a challenge and its effective implementation needed commitment on the part of the teachers.

The findings of the current study complement those of Tuan's (2010) and Endeshaw's (2015). Tuan (2010) investigated EFL students' learning styles and their attitudes towards CL in Vietnam. The author claimed that 89 percent of the students in the experimental group declared that the use of CL improved their understanding of the course content. The results thus obtained in the current study also complement those of Endeshaw's (2015). Endeshaw (2015) conducted a study on the effect of STAD on EFL students' reading comprehension. The author concluded that $\mathrm{CL}$ was a practical method of teaching that improved reading comprehension of the students. The findings of the current study also support the use of CL in Saudi EFL classrooms. However, the study in hand is unique in the sense that it endeavored to investigate the scope of CL in Saudi EFL classrooms as envisaged by EFL teachers in Saudi Arabia.

\section{CONCLUSION}

This research study presents a pleasing picture about the scope of CL based teaching in EFL classes particularly in Saudi Arabia. The practitioners in the EFL field are ready to receive it with open arms as they feel that it will have positive impact on the proficiency level of the adult learners. There is a strong realization among them that CL strategies are equally beneficial for high, medium and low achievers in the adult EFL learners' classes. They feel that they can help develop Saudi adult EFL learners' self-confidence by encouraging them to participate actively using different CL strategies. Thus, they will be able to make Saudi adult learners more responsible and more motivated as compared to making them work individually as they have been doing using the traditional teaching approaches, methods and techniques. EFL teachers can also develop a sense of achievement in Saudi adult EFL learners by using different CL strategies. CL strategies can make the classes more interactive, productive and student-centered as they give Saudi adult EFL learners more opportunity to talk/speak/actively participate as compared to traditional methods of teaching. What is required, however, is that the teachers must be supported, facilitated and encouraged by the administrators and cooperated with by the learners in using the CL strategies to overcome the barriers coming their way.

\section{RECOMMENDATIONS}

Following are some recommendations in the light of present research study to improve the English language/teaching scenario in Saudi Arabia and enhance the proficiency level of adult EFL learners through CL based teaching in the classes:
- People at the helms of affairs must rectify their misconception that there is a lack of will on the part of EFL teachers to bring innovations in their teaching practices and that they will prove to be the barriers in implementing CL based teaching practices in the EFL classes for adult learners.

- All EFL teachers in general and EFL teachers in Saudi Arabia in particular should try to learn, use and integrate CL strategies in their teaching practice. Administrators and policy makers should encourage and facilitate them in this regard.

- The main barriers in the way of implementing CL strategies in the classes are some of the EFL students who have developed wrong learning habits. Administrators and teachers need to make collaborative efforts to counsel them on the right learning track. Teachers' efforts to develop teacher-student, student-student and student- teacher interaction in the class as a result of CL strategies are resisted by some Saudi adult learners as they don't want to work with others. It is recommended to conduct research to find out the social and psychological factors which lead to this kind of resistance to CL based teaching in Saudi adult EFL learners to find out the remedies in this regard.

- EFL teachers need special cooperation and facilitation to overcome the initial resistance from the learners when CL strategies are implemented in the classes.

- EFL teachers also need pre-service and in-service training to get transformed from traditional teaching practices to the innovative and productive CL based teaching practices.

- There is a strong need to bring awareness in all the stakeholders (teachers, students and administrators) involved in English language teaching/learning particularly in Saudi Arabia that the adult learners' social, collaborative, psychological and linguistic skills can be improved immensely by using CL strategies. Awareness campaign should also highlight that if different CL strategies are used in the class, they can change the classroom atmosphere from traditional to modern and help develop the adult EFL learners' language proficienc . They should be made to realize that the atmosphere of cooperation among the team-mates and competition among the teams as a result of CL strategies can lead to speedy proficiency development in the learners. In short, CL strategies can give Saudi adult EFL learners a social environment, active learning experience and equal opportunity to learn the target language. It is recommended to arrange periodic seminars in the departments to this effect.

- The difference in the attitude of EFL female teachers and EFL male teachers should be bridged by allowing them combined department meetings through video conferences. This will allow them to exchange their ideas regarding the difficulties and barriers in the way of implementing CL strategies in the classes and help them reach an improved and unified vision to improve the English language proficiency of Saudi adult EF learners. 


\section{REFERENCES}

Abdel Rauf, A. (2010). Grammar-translation method: Still alive in Arab TEFL classroom. TESOL Arabia Perspectives, 17 (1), 13-18.

Alijanian, E. (2012). The effect of student teams achievement division technique on English achievement of Iranian EFL learners. Theory and Practice in Language Studies, 2(9), 1971-1975.

Assalahi, H.M. (2013). Why is the Grammar-translation Method Still Alive in the Arab World? Teachers' beliefs and its implications for EFL teacher education. Theory and Practice in Language Studies 3(4): 589-599.

Chianson, M.M., Kurameh, M.S., \& Obida, J.A. (2010). Effect of cooperative learning strategy on students' retention in circle geometry in secondary schools in Benue State, Nigeria. American Journal of Scientific and Industrial Research. 2(1), 33-36.

Davoudi, A.H. M. \& Mahinpo, B. (2012). Kagan cooperative learning model: The bridge to foreign language learning in the third millennium. Theory and Practice in Language Studies. 2(6): 1134-1140.

Gillies, R. M., \& Boyle, M. (2010). Teachers' reflections on cooperative learning: Issues of implementation. Teaching and Teacher Education, 26(4), 933-940.

Haydon, T., Maheady, L., and Hunter, W. (2010). Effects of numbered heads together on the daily quiz scores and on-task behavior of students with disabilities. Journal of Behavioral Education. 19(3): 222-238.

Heath, T.J. (2010). The Impact of a Cooperative Learning Training Program on Teacher Perceptions about Cooperative Learning. (Unpublished doctoral dissertation). Walden University, Minneapolis, Minnesota, United States.

Ishtiaq, M., Ali, Z., \& Salem, M. (2015). The effects of student teams achievement division (STAD) on motivation of Saudi EFL adult learners. International Journal of Language Education and Applied Linguistics, 3, 11-24.

Javid, C. Z., Farooq, U., \& Gulzar, M. A. (2012). Saudi English-major undergraduates and English teachers' perceptions regarding effective ELT in the KSA: A comparative study. European Journal of Scientific Research, 85(1), 55-70.

Johnson, D.W., \& Johnson, R.T. (2009). An Educational Psychology Success Story: Social Interdependence Theory and Cooperative Learning. Educational Researcher 38(5): 365-379.

Kagan, S., \& Kagan, M. (2009). Cooperative learning. San Clemente, CA: Kagan Publishing.

Khan, S.A., Javaid, M.A. \& Farooq, U. (2015). Evaluation of the effectiveness of cooperative learning method versus traditional learning method on the writing ability of the students. Asian Journal of Management Sciences \& Education, 4 (1), 23-32.

Khan, G.N. \& Inamullah, H.M. (2011). Effect of student's team achievement division (STAD) on academic achievement of students. Asian Social Science, 7(12), 211-215.

Kohn, A. (1992). Resistance to cooperative learning: making sense of its deletion and dilution. Journal of Education, 174, 38-55.

Law, Y. K. (2011). The effects of cooperative learning on enhancing Hong Kong fifth graders' achievement goals, autonomous motivation and reading proficienc . Journal of Research in Reading, 34(4), 402-425.

Maherzi, S. (2011). Perceptions of classroom climate and motivation to study English in Saudi Arabia: Developing a questionnaire to measure perceptions and motivation. Electronic Journal of Research in Educational Psychology. 9(2): 765-798.

Mahmoud, M.M.A. (2014). The effectiveness of using the cooperative language learning approach to enhance EFL writing skills among Saudi university students. Journal of Language Teaching and Research, 5(3), 616-625.

Mohseny, A. \& Jamour, F. (2012). The impact of student team achievement division on vocabulary learning of Iranian EFL pre-intermediate learners. International Electronic Journal for the Teachers of English, 2(6), 105-129.

Pan, C.Y. \& Wu, H.Y. (2013). The cooperative learning effects on English reading comprehension and learning motivation of EFL freshmen. English Language Teaching, 6(5), 13-27.

Slavin, R. E. (2010). Co-operative learning: What makes group work work? In H. Dumont, D. Istance, \& F. Benavides (Eds.), The nature of learning: Using research to inspire practice. (pp. 161-178). Paris, France: OECD.

Slavin, R.E., (2011), Instruction based on cooperative learning. In Mayer, R.E. and Alexander, P.A., (Eds.), Handbook of Research on Learning and Instruction (pp. 344360), New York: Routledge.

Slavin, R.E. (2009). Cooperative learning. In G. McCulloch \& D. Crook (Eds.), International Encyclopedia of Education. Abington, UK: Routledge.

Slavin, R.E. (1995). Cooperative learning: Theory, research, and practice (2 $\left.2^{\text {nd }} E d.\right)$. Boston: Allyn \& Bacon

Stokes, P. \& Wall, T. (2014). Research Methods. London: Palgrave

Storch, N., \& Aldosari, A. (2012). Pairing learners in pair work activity. Language Teaching Research. 17: 31-48.

Tran, V.D. (2014). The effects of cooperative learning on the academic achievement and knowledge retention. International Journal of Higher Education 3 (2): p-131.

Van Wyk, M.M. (2010). Do student teams' achievement divisions enhance economic literacy? A quasi experimental design. Journal of Social Science, 23(2): 83-89.

Van Wyk, M.M. (2012). The effects of the STAD-cooperative learning method on student achievement, attitude and motivation in economics education. Journal of Social Science, 33(2), 261-270.

Wallestad, C. K. (2010). Prospective TESOL teachers' beliefs, understandings, and experiences of cooperative learning. State University of New York at Buffalo.

Wang, T.P. (2009). Applying Slavin's cooperative learning techniques to a college EFL conversation class. The Journal of Human Resource and Adult Learning 5(1): 112-120. 
Wang, M. (2012). Effects of cooperative learning on achievement motivation of female university students. Asian Social Science, 8(15), 108-114.

Zain, Z. M., Subramaniam, G., Rashid, A. A., \& Ghani, E. K. (2009). Teaching economics using cooperative learning approach: Accounting students' performance and attitude. Canadian Social Science, 5(6), 92-102.

Zhou, H. (2012). Enhancing non-English majors' EFL motivation through cooperative learning. Procedia Environmental Sciences, 12, 1317-1323. 